Research Article

www.ijrap.net

\title{
COMPARATIVE STUDIES ON ANTHELMINTIC POTENTIAL OF CUCURBITA MAXIMA (PUMPKIN) SEEDS AND CARICA PAPAYA (PAPAYA) SEEDS
} Sengupta Rupa $^{1}$, Banik Jayanta ${ }^{2}$

${ }^{1}$ Assistant professor, Department of Pharmacognosy, ROFEL, Shri G. M. Bilakhia College of Pharmacy, Namdha Road, Vapi, Gujarat, India

${ }^{2}$ Assistant Manager-Production, Formulation Department, USV Limited, OIDC, Mahatma Gandhi Udyog Nagar, Dabhel, Daman

Received on: 12/05/13 Revised on: 28/06/13 Accepted on: 18/07/13

*Corresponding author

E-mail: rupasengupta222@rediffmail.com

DOI: 10.7897/2277-4343.04415

Published by Moksha Publishing House. Website www.mokshaph.com

All rights reserved.

\section{ABSTRACT}

The crude extract of Carica papaya (papaya) seeds (CP) and Cucurbita maxima (Pumpkin) seeds (CM) were assayed against adult earthworms (Pheretima posthuma) for the evaluation of anthelmintic activity. Various concentrations of both extracts were tested and results were expressed in terms of time for paralysis (P) and time for death (D) of worms. Albendazole was used as a reference standard. The result showed that in both of the extracts (i.e. CP and CM) dose of $60 \mathrm{mg} / \mathrm{ml}$ possesses more wormicidal activity. The time of paralysis was $1.88 \pm 0.52$ minute and $1.93 \pm 0.57$ minute whereas the time of death was $3.45 \pm 0.17$ minute and $4.90 \pm 0.18$ minute in the case of Carica papaya and Cucurbita maxima respectively. In conclusion, the use of seeds of Carica papaya (CP) and Cucurbita maxima (CM) for anthelmintic activity have been confirmed and further studies are suggested to isolate the active principles responsible for the activity. Both the extracts showed significant anthelmintic activity, but the comparative study showed that out of these two, Carica papaya proves to be a better anthelmintic remedy.

Keywords: Anthelmintic, Pheretima posthuma, Cucurbita maxima, Albendazole, Carica papaya.

\section{INTRODUCTION}

The World Health Organization estimates that a staggering two billion people harbor parasitic worm infections. Development of resistance to most of the commercially available anthelmintics became a severe problem worldwide ${ }^{1}$. Moreover, these drugs are unaffordable, inaccessible or inadequately available to the poor farmers of the developing countries ${ }^{2}$. These factors paved the way for herbal remedies as alternative anthelmintics ${ }^{3}$. Evaluation of the activities of medicinal plants claimed for possessing the anthelmintic property is getting attention these days ${ }^{4,5}$. Screening and proper evaluation of the claimed medicinal plants could offer possible alternatives that may be both sustainable and environmentally acceptable ${ }^{5}$. In the current study, we have attempted to investigate pumpkin seeds and papaya seeds for their claimed anthelmintic activity. Cucurbita maxima Duch. (Family Cucurbitaceae) commonly known as Squash is widely used as vegetable and a source of vitamin A, iron, phosphorus and calcium. The fruits after harvest can be stored many months, if kept dry. Research on this plant reported that Spinasterol isolated from the flowers of Cucurbita maxima showed potential anticarcinogenic, antigenotoxic ${ }^{6}$, antimutagenic and antitumorigenic activity ${ }^{7}$. The seeds were used in the treatment of liver and digestive disorders ${ }^{8}$, while the oil from the seeds exhibited anthelmintic property ${ }^{9}$. Carica papaya L. (family Caricaceae) is a fast growing small tree, about 5-10 meter in height with straight, cylindrical, soft; hollow, grey trunk roughened by the presence of large leaf- and inflorescence scars. Papaya fruit is a source of nutrients such as provitamin A, carotenoids, vitamin $\mathrm{C}$ and dietary fiber. Papaya skin, pulp and seeds also contain a variety of phytochemicals, including lycopene and polyphenols. It is cultivated in tropical countries mainly in Australia, Hawai, India, Sri Lanka, Philippines, South Africa and Nigeria. Its seeds are black, tuberculous and enclosed in a transparent aril. The seeds are considered as carminative, emmenagogue, abortifacient, vermifuge, thirst quencher and counterirritant. Seed extract is used to treat bleeding piles and enlarged liver and spleen. Seed paste with glycerine can be applied to cure ringworm and psoriasis ${ }^{10}$. The ripe seeds are taken with rice and useful to treat diarrhoea. The seeds are effective to control diabetes mellitus, hypertension and hypercholesterolemia ${ }^{11-13}$. A seed decoction is beneficial to cure liver and renal disorders ${ }^{14}$. The seeds contained a fixed oil composed of myristic, palmitic, stearic, arachidic, behenic and unsaturated fatty $\operatorname{acids}^{15}$, phospholipids, carpaine, benzylisothiocyanate, benzyl glucosinolate, glucopaeolin ${ }^{16}$, hentriaontane, $\beta$ sitosterol $^{17}$, caricin (sinigrin) and myosine. The papaya seed extracts showed antifertility effect ${ }^{18-22}$, inhibited jejunal contraction and suppressed cauda epididymal sperm motility $^{23,24}$.

\section{MATERIALS AND METHODS}

The methodology adopted to evaluate the anthelmintic activity of seeds of Cucurbita maxima (pumpkin) and Carica papaya (papaya).

\section{Plant Material}

The seeds of Cucurbita maxima (pumpkin) and seeds of Carica papaya (papaya) were collected. The seeds were identified, authenticated and Voucher herbarium specimen was deposited in the Department of Pharmacognosy of ROFEL, Shri G. M. B College of Pharmacy for future reference bearing Nos-RPC/RS/003 
and RPC/RS/004 respectively. The seeds were shadedried, grinded and stored in room temperature in a closed container for further use.

\section{Preparation of Extract}

The seeds are procured from pumpkin and papaya from the local market of Vapi, India. Seeds are dried at about $50^{\circ} \mathrm{C}$ in hot air oven for over-night then pulverized to course powder, extracted by Soxhlet using $70 \%$ (v/v) Hydro-alcoholic solution. Both extracts were dried at $40-$ $60^{\circ} \mathrm{C}$.

\section{Worm Collection and Authentication}

Indian adult earthworms (Pheretima posthuma) were collected (due to its anatomical and physiological resemblance with the intestinal roundworm parasites of human being) from moist soil and water logged areas at Vapi, Namdha Road, India and was identified at the Department of Pharmacology, ROFEL, Shri G. M. B College of Pharmacy Vapi, India. Then all collected worms were washed with normal saline to remove all the faecal matter and used for the anthelmintic study. The earthworms of 3-5 cm in length and 0.1-0.2 cm in width were used for all the experimental protocol.

\section{Sample Preparation}

The solutions of pumpkin seed extract (CM), Papaya seed extract (CP) and albendazole were made in the concentrations of $20,40,60 \mathrm{mg} / \mathrm{ml}$ in normal saline as vehicle.

\section{Drugs and Chemicals}

Albendazole (BANDY, Mankind Pharma Ltd., New Delhi, India), Saline water (Claris Life sciences Ltd., Ahmedabad, India)

\section{Anthelmintic Activity}

The anthelmintic activity was performed according to the method of Ghosh et $a l^{25}$ on adult Indian earthworm Pheritima posthuma as it has anatomical and physiological resemblance with the intestinal roundworm parasites of human beings ${ }^{26,27}$. Pheritima posthuma worms are easily available and used as suitable model for screening anthelmintic drugs ${ }^{28}$. Ten groups were made, each containing six adult earthworms of approximately equal size. The solutions of Papaya seed extract (CP), Pumpkin seed extract (CM) and albendazole were made in the concentrations of 20,40,60 $\mathrm{mg} / \mathrm{ml}$ in normal saline as vehicle. Groups of earthworms were released into $10 \mathrm{ml}$ of desired formulations as made above and one group was treating as control in normal saline. The observation was made for the time taken to cause paralysis and death of individual worms. Paralysis was said to occur when the worms did not move even in normal saline. Death was concluded when the worms lost their motility followed by fading away of their body colours.

\section{RESULTS}

As shown in Table 1, Papaya seed extract (CP) and Pumpkin seed extract (CM) exhibited anthelmintic activity in dose-dependent manner giving shortest time of paralysis (P) and death (D) with $60 \mathrm{mg} / \mathrm{ml}$ concentration. The Papaya seed extract (CP) caused paralysis $(\mathrm{P})$ of 1.88 minutes and time of death (D) of 3.45 minutes. While Pumpkin seed extract (CM) revealed paralysis of 1.93 and death of 4.9 minutes. respectively against the earthworm Pheretima posthuma. The reference drug, albendazole showed paralysis at 1.15 and 3.23 minutes respectively.

Table 1: Anthelmintic Potential of Cucurbita maxima (CM) Seeds and Carica papaya (CP) Seeds

\begin{tabular}{|c|c|c|c|}
\hline Treatment & Concentration used in mg / ml & Time taken for paralysis (minutes) & Time taken for death (minutes) \\
\hline Control (Normal Saline) & - & No paralysis (up to 7.2 minutes) & No paralysis (up to7.2 minutes) \\
\hline \multirow{3}{*}{ CP extract } & 20 & $2.43 \pm 0.08$ & $6.16 \pm 0.42^{* *}$ \\
\cline { 2 - 4 } & 40 & $2.12 \pm 0.64$ & $4.81 \pm 0.54^{* *}$ \\
\cline { 2 - 4 } & 60 & $1.88 \pm 0.52$ & $3.45 \pm 0.17 * *$ \\
\hline \multirow{2}{*}{ CM extract } & 20 & $2.93 \pm 0.81$ & $7.20 \pm 0.72^{*}$ \\
\cline { 2 - 4 } & 40 & $2.57 \pm 0.58$ & $6.32 \pm 0.48^{*}$ \\
\cline { 2 - 4 } & 60 & $1.93 \pm 0.57$ & $4.90 \pm 0.18^{*}$ \\
\hline Albendazole & 20 & $1.93 \pm 0.78$ & $5.55 \pm 0.34$ \\
\cline { 2 - 4 } & 40 & $1.44 \pm 0.55$ & $4.12 \pm 0.44$ \\
\cline { 2 - 4 } & 60 & $1.15 \pm 0.38$ & $3.23 \pm 0.88$ \\
\hline
\end{tabular}

Each value represents mean \pm S.D $(\mathrm{N}=6)$, analyzed by Dunnett's'test $*=\mathrm{p}<0.01, * *=\mathrm{p}<0.05$. This activity was Concentration dependent. The potency was found to be inversely proportional to the time taken for paralysis and time of death of the worms

\section{DISCUSSION}

Albendazole by increasing chloride ion conductance in worms muscle membrane produce hyperpolarization and reduce excitability that which led to muscle relaxation and flaccid paralysis ${ }^{29}$. Phytochemical screening of the Carica papaya extracts revealed the presence of alkaloids, saponins, flavonoids, triterpenes, tannins, steroids, phenols, phytate and steroids etc. The phytochemical and pharmacological studies performed indicated the different extracts (petroleum ether, ethyl acetate and alcohol) of Cucurbita maxima also contain carbohydrates, flavonoids, tannins, phenolics and saponins ${ }^{30}$. The presence of tannins in the seed of Carica papaya can support its strong use for healing of wounds, ulcers, hemorrhoids, frost-bites and burns in herbal medicine ${ }^{31}$. Tannins were shown to produce anthelmintic activities, chemically tannins are polyphenolic compounds. It is possible that tannins contained in the extracts of Carica papaya and Cucurbita maxima produced similar effects. Reported anthelmintic effect of tannins is that they can bind to free proteins in the gastrointestinal tract of host animal or glycoprotein on the cuticle of the parasite and may cause death. The exact mechanism of the anthelminthics activity of Carica papaya and Cucurbita maxima cannot be explained on the basis of our present results. From the observations made, higher concentration of extract produced paralytic effect 
much earlier and the time to death was shorter for all worms. Further studies are in process to identify the possible phytoconstituents responsible for anthelmintic activity. As seeds are cheap, easily available in the local market, therefore seeds of these plants could be categorized under Anthelmintic herbal drugs and could become a key ingredient of Anthelmintic herbal formulation.

\section{CONCLUSION}

From the above result it is concluded that extract of seeds of Carica papaya (CP) have a potent anthelmintic activity when compared with extract of seeds of Cucurbita maxima (CM) as Carica papaya has taken lesser time in terms of paralysis and death. It is comparable with standard drug. Further studies using in vivo model are required to find out and to establish effectiveness and pharmacological rationale for the use of these seeds as anthelmintic drug. The experimental evidence obtained in the laboratory model could provide a rationale for the traditional use of these two plants seeds as anthelmintic. These seeds may be further explored for its phytochemical profile to recognize the active constituent responsible for anthelmintic activity.

\section{ACKNOWLEDGEMENT}

The authors are thankful to the management of ROFEL, Shri G.M. Bilakhia College of Pharmacy, Vapi, Gujarat, India for providing laboratory facilities to carry out the research work.

\section{REFERENCES}

1. Waller PJ, Thamsborg SM. Nematode control in green ruminant Production systems. Trends Prasitol 2004; 20: 493-7. http://dx.doi. org/10.1016/j.pt.2004.07.012 PMid:15363444

2. Hammond JA, Fielding D, Bishop SC. Prospects for plant anthelmintics in tropical veterinary medicine. Vet Res Commun 1997; 21: 213-28. http://dx.doi.org/10.1023/A:1005884429253 PMid:9090048

3. Fajmi AK, Taiwo AA. Herbal remedies in animal parasitic diseases in Nigeria: A review. Afr J Biotec 2005; 4: 303-7.

4. Gathuma JM, Mbaria JM, Wanyama J, Kaburia HF, Mpoke L, Mwangi JN, et al. Efficacy of Myrsine africana, Albizia anthelmintica and Hilderbrantia sepalosa herbal remedies in Samburu district, Kenya. J Ethnopharmcol 2004; 91: 7-12. http://dx. doi.org/10.1016/j.jep.2003.11.007 PMid:15036460

5. Githiori JB. Evaluation of anthelmintic properties of ethnoveterinary plant preparations used as livestock dewormers by pastoralists and smallholder farmers in Kenya. Doctoral Thesis, Swedish University of Agricultural Sciences, Uppsala, Sweden; 2004.

6. Villasenor IM, Lemon P, Palileo A and Bremner JB. Antigenotoxic spinasterol from Cucurbita maxima flowers. Mutat Res 1996; 360(2): 89-93. http://dx.doi.org/10.1016/0165-1161(95)00071-2

7. Villaseñor IM and Domingo AP. Anticarcinogenicity Potential of spinasterol Isolates from Squash Flowers. Teratogenesis, Carcinogenesis and Mutagenesis 2000; 20: 99-105. http://dx.doi .org/10.1002/(SICI)1520-6866(2000)20:3<99::AIDTCM1>3.0.CO; 2-7

8. Prokhvatilova SS, Mikhalev V, Prokhovora LV, Evtushenko NS, Antonova NP and Simonova EP. HPLC Determination of $\alpha$ tocopherol in tykveol preparation. Farmatsiya (Moscow) 1998; 47(5): 31-32.

9. Basaran AA, Ciftci KF and Kusmenoglu S. Characteristics of Turkish Cucurbita maxima Duch seed oil. Acta Pharmacologica Turc 1998; 40(1): 17-19.

10. Publication and Information Directorate, CSIR; New Delhi, India. Anonymous, The Wealth of India, Raw Materials 1992; 3: 276-9.
11. Mhaskar KS, Blatter E, Caius JF, editors. Kirtikar and Basu's Illustrated Indian Medicinal Plants Delhi: Sri Satguru Publications 2000; 5: 1526-9.

12. Parrotta JA, editor. Healing Plants of Peninsular India, Wallingford, UK: CABI Publishing; 2001. p. 202-3.

13. Gill LS, editor. Ethnomedicinal uses of plants in Nigeria,Carica papaya L; Benin City: Uniben Press; 1992. p. 57-8.

14. Adeneye AA, Olagunju JA, Banjo AAF, Abdul SF, Sanusi OA, Sanni OO, et al. The aqueous seed extract of Carica papaya Linn. Prevents carbon Tetrachloride induced hepatotoxicity in rats. Int $\mathrm{J}$ Appl Res Nat Prod 2009; 2: 19-32.

15. Puangsri T, Abdulkarim SM, Ghazali HM. Properties of Carica papaya L. (Papaya) seed oil following extractions using solvent and aqueous enzymatic methods. J Food Lipids 2005; 12: 62-76. http:// dx.doi.org/10.1111/j.1745-4522.2005.00006.x

16. Rossetto MR, Oliveira Do Nascimento JR, Purgatto E, Fabi JP, Lajolo FM, Cordenunsi BR. Benzyl glucosinolate, benzylisothiocyanate and myrosinase activity in papaya Fruit during development and ripening. J Agric Food Chem 2008; 56: $9592-$ 9. http://dx.doi.org/10.1021/jf801934x PMid:18826320

17. Rastogi RP, Mehrotra BN, editors. Compendium of Indian Medicinal Plants; New Delhi, India: Central Drug Research Institute and Publication and Information Directorate; 1993. p.135.

18. Lohiya NK, Goyal RB, Jayaprakash D, Ansari AS, Sharma S. Antifertility effects of aqueous extract of Carica papaya seeds in male rats. Planta Med 1994; 60: 400-4. http://dx.doi.org/10.1055/s2006-959518 PMid:7997464

19. Chinoy NJ, D'Souza JM, Padman P. Effects of crude extract of Carica papaya seeds in male albino mice. Reprod Toxicol 1994; 8: 75-9. http://dx.doi.org/10.1016/0890-6238(94)90070-1

20. Adebiyi A, Ganesan AP, Prasad RN. Tocolytic and toxic activity of papaya seed extract on isolated rat uterus. Life Sci 2003; 74: 58192. http://dx.doi.org/10.1016/j.lfs.2003.06.035 PMid:14623029

21. Udoh P, Essien I, Udoh F. Effect of Carica papaya (paw paw) seeds extract on the morphology of pituitary-gonadal axis of male Wistar rats. Phytother Res 2005; 19: 1065-8. http://dx.doi.org/10.1002 ptr.1388 PMid:16372375

22. Manivannam B Mittal, Goyal S, Ansari AS, Lohiya NK. Sperm characteristis and ultra structure of testes of rats after long-term treatment with the methanol subfraction of Carica papaya seeds. Asian J Androl 2009; 11: 583-99. http://dx.doi.org/ 10.1038/aja.2009.25 PMid:19648937

23. Adebiyi A, Adaikan PG. Modulation of jejunal contractions by extract of Carica papaya L. seeds.Phytother Res 2005; 19: 62832. http://dx.doi.org/10.1002/ptr.1706 PMid:16161026

24. Verma RJ, Nambiar D, Chinoy NJ. Toxicological effects of Carica papaya seeds extract on spermatozoa of mice. J Appl Toxicol 2006; 26: 533-5. http://dx.doi.org/10.1002/jat.1173 PMid:17080407

25. Ghosh T, Maity TK, Bose A, Dash GK. Anthelmintic activity of Bacopa monierri. Indian J Nat Product 2005; 21: 16-19.

26. Girme AS, Bhalke RD, Ghogare PB, Tambe VD, Jadhav RS, Nirmal SA. Comparative In vitro Anthelmintic Activity of Mentha piperita a Lantana camara from Western India.Dhaka Univ J Pharm Sci 2006; 5: 5-7.

27. Tambe VD, Nirmal SA, Jadhav RS, Ghogare PB, Bhalke RD, Girme AS, Bhamber RS. Anthelmintic activity of Wedelia trilobata leaves. Ind J Nat Prod 2006; 22: 27- 29.

28. Dash GK, Sursh P, Sahu SK, Kar DM, Ganpaty S, Panda SB. Evaluation Evolvulus alsinoids Linn. for anthelmintic and antimicrobial activities. J Nat Rem 2002; 2: 182-85

29. Mali RG, Mahajan S, Patil KS. Anthelmintic activity of root bark of Capparis spinosa. Indian J Nat Prod 2005; 21: 50-51.

30. Marles RJ and Farnsworth NR. Antidiabetic plants and their active constituents. Phytomedicine 1995; 2: 137-189. http://dx.doi.org/ 10.1016/S0944-7113(11)80059-0

31. EI Okoye. Preliminary phytochemical analysis and antimicrobial activity of seeds of Carica papaya, journal of basic physical research 2011; 2(1): 66-69.

\section{Cite this article as:}

Sengupta Rupa, Banik Jayanta. Comparative studies on anthelmintic potential of Cucurbita maxima (Pumpkin) seeds and Carica papaya (Papaya) seeds. Int. J. Res. Ayurveda Pharm. 2013;4(4):530-532 http:// dx.doi.org/10.7897/2277-4343.04415 